\title{
Implications of Organisational Culture on Performance of Business Organisations
}

\author{
Emerole Gideon A (Ph.D) ${ }^{1,}$ Kenneth Ebibou Sonrandein ${ }^{2}$, Edeoga Georgina .I. ${ }^{3}$ \\ Department of Business Administration College of Management Sciences Michael Okpara University of \\ Agriculture, Umudike Umuahia Abia State. \\ Federal University Otuoke, Bayelsa State, Nigeria \\ Department of Human Resource Management College of Management Sciences Michael Okpara University of \\ Agriculture, Umudike Umuahia Abia State.
}

\begin{abstract}
This article discusses the implications of organizational culture on the performance of business organizations in Nigeria. The first objective of the paper is to elaborate on organisational culture as a determinant of organisational performance. The second objective is to identify four dimensions of African culture as bases for more effective organization culture in the Nigerian context. Works of well known authors in the fields of Culture and Management were reviewed for perspectives and evidence. It is shown from the reviews that a relationship exists between organisational culture and performance of business organisations. In addition, the review suggests that relationship is mediated by reward perception and role perception. Social support, accommodation at work places, religious referencing, supervisor-subordinate age ratio and ethnic diversification are identified as culture factors likely to have positive impact on the performance of business organisations in Nigeria. It is recommended that business organizations in the country should give adequate attention to the development of corporate cultures that integrate the above factors in order to enhance their performance.
\end{abstract}

Keywords: Organisational Culture, Performance, Business Organisations.

\section{Introduction}

In most societies, work organisations constitute the basis of the economy. The significance of work organisations has been recognised since the Industrial Revolution and organisations have been considered as the key to the transformation of several societies from agrarian to modern industrial ones. The continued progress and prosperity of modern societies has been attributed to the activities of work organisations. For instance, Cole (1967:90) asserts that organisations account for more than half of the economic activities in the United States. Moreover, as has been observed by Simon (Loasby, 2007), the natural appearance of modern economies is of dense organizational clusters with market connections and most economic activities take place in organizations. On the other hand, economic failure can be located in defective firms. Certainly, organizations determine modern economies. Consequently, there is a continuous search for performance improvement of business organisations in contemporary societies.

The spin-offs from performance of business organisations, especially for labour, are noteworthy. All things being equal, the net returns and the wages and salaries of employees of an economic organisation depend on the performance of the organisation.

Secondly, organisational performance is important for employment generation. This is so because, firms will increase their labour force as long as the value of the marginal product of labour is higher than the cost thereof e.g. wages. Therefore, all things being equal, increasing organisational performance will increase the marginal product of labour and hence the level of employment (Yesufu, 1984:170).

Organisations in Africa, especially those in the public sector, are particularly challenged with respect to their effectiveness and competiveness. Obviously, contrary to expectations, African countries lag far behind their European counterparts in terms of economic progress in spite of their adoption of organisational forms of production for a considerable time. The desire to address this developmental gap provides an impetus for the search for an appropriately effective performance improvement strategy. Consequently, the exploration of human resources becomes a preferred alternative.

Strong attention on human resources is arguably a preferable option for organisations in Africa to improve their performance because the countries are abundantly endowed with these resources as opposed to technological and financial ones. Moreover, such attention is underscored by the view that economic progress is basically as a result of human effort (Paprock, 2006) and is in line with contemporary management focus which views workforce capacity or labour as the decisive source of competitive advantage (Peters, 2009; Ghosh and Geetika, 2007; Lynham and Cunningham, 2006; Ozcelik and Ferman, 2006) as opposed to land and capital. 
However, the effectiveness of the management of human resources in African work-places, particularly in Nigeria, has been questionable. For instance, the attitude to work in modern African workplaces has been assessed as low compared to that of their counterparts in western industrialized nations (Ahiauzu, 1999:11) in spite of the adoption of the western management practices in African societies. Differences in work outcome based on the same management practice have also been observed concerning some other nations (Chiang and Birch, 2007).

Consistent with western management practices, scholarly works indicate that much of the performance improvement efforts concentrate on financial rewards (e.g. Chang and Birch, 2007). Research has indicated the negative effects of financial rewards. Sachau (2007) suggests that 'offering people financial reward for performing an interesting activity will undermine interest in the activity' and that wealth is unrelated to longterm satisfaction. In particular, increase in financial rewards does not lead to a corresponding increase in work performance. For instance, Olisa (1985:147) observes that employees in government corporations in Nigeria earned more pay but performed poorer than their counterparts in the private sector, especially the foreign-owned enterprises. Secondly, it was observed in Enugu state of Nigeria that, while public primary schools with well trained and well-paid staff are not doing well, private primary schools with poorly paid staff are doing well (Njoku, 2011). It is also believed that 'focusing attention on pay and security will lead to escalating expectations and will be very expensive for the organisation' (Sachau, 2007).

Particularly, Human Resource Management (HRM) financial reward practices are believed to be less efficient in contexts other than the Western countries. Underlying this belief is that HRM financial reward practices which are based on efficiency principles, originated from Western nations, especially the United States and though acknowledged to be effective in these countries have no consideration for peculiarities in nonwestern European countries. The tendency therefore has been to standardize these rewards practices across borders. Managers tend to adopt those practices they perceive as being effective in other jurisdictions with the underlying belief that these practices could be universalized.

Differences of levels of performance across countries and even groups from the application of financial rewards have directed attention to the consideration of non-financial factors including culture in the management of performance of business organisations in Nigeria. Culture is believed to negatively influence work behaviour in Nigeria (Ahiauzu, 1999:11). On the contrary, can the African culture be managed to increase organisational performance in Nigeria? The purpose of this article is to provide an elaboration on the relationship between organization culture and performance in business organizations. The second purpose is to identify some dimensions of African culture that can be useful for the management of organization culture in business organizations in Nigeria. The next section of this article provides a basis for the use of a cultural approach in the management of performance. The third section of the article identifies specific cultural variables unique to the African and Nigerian work context which can be useful for performance improvement. The article concludes by recommending the exploitation of these variables for the management of performance of business organisations in Nigeria and by providing suggestions for further research in the culture field of study.

\section{Organisational Culture As A Framework For Improving Organizational Performance}

There are various approaches to the conception of organization culture. Prominent among these are Integration, Differentiation and Fragmentation approaches (Hill and Carley, 2008). The Integration approach views organizational culture as a "set of shared values that help organisational members understand organisational functioning and thus guide their thinking and behaviour" (Jaskyte and Dressler, 2004; Hill and Carley, 2008). The approach focuses on the manipulation of various components of culture to ensure that employees adopt management ideas without objection. It asserts that the managerial group creates and manages organisational culture.

The differentiation approach suggests that the creation and adoption of culture is influenced by informal social relationships and occurs at the subgroup level in the organisation. According to this approach, culture makes groups of individuals focus on the differences in values, practices and organisational priorities. While culture facilitates agreements to occur within groups, it makes differences between groups to be salient. The fragmentation approach holds that culture is idiosyncratic and is uniquely understood by individuals as a result of their identity, role or position in the organisation. The approach asserts that transmission of culture is influenced by interpersonal relationships between an individual and another person of similar interests in the organisation.

The 'organisational culture' approach in organisations developed in the 1980s when organisation theorists started referring to organisations as 'socially constructed systems of meanings' and then started systematically applying the term 'Culture' to organisations. This is sequel to the increasing performance of Japanese firms over American firms that were attributed to differences in culture (Lim, 1995; Morrill, 2008).

The beginning of the recognition of the influence of culture in organizations could be traced to as far back as the period of the industrial revolution. Salaman (1980) accounts that entrepreneurs early in the industrial 
revolution recognised the need to destroy pre-industrial habits and moralities of workers in order to make them amenable to the rigors of industrial work. Accordingly, great efforts were made to inculcate in the workers morally responsible and respectable behaviours. Attention was focused on the workers' characters, sexual morals, drinking habits, and religious devotions. It was believed that this was necessary for the workers to be obedient and responsive to the employers' controls and sanctions. According to Salaman (1980), the workers were exposed to intensive cultural bombardment.

Further, recognition of the role of culture in organizations had also been given by early organisation theorists. Frederick Taylor and Henry Fayol, while pursuing the rational approach in their theories, unwittingly acknowledged the important role of culture in organisations (Morrill, 2008). Others such as Max Weber of Bureaucracy fame, Parsons and Bernard also explicitly acknowledged the influence of culture on economic action (Giddens, Duneler \& Appelbaum, 2005:15;Morrill, 2008;Bocock,1981:7).

The recognition of the relevance of culture in organizational processes got to a turning point following the Hawthorne experiments (Morrill, 2008). Researchers at the AT\& T Hawthorne Assembly Plant near Chicago discovered that non-rational values such as norms and sentiments influenced productivity. The discovery was made during lighting experiments at the plant. Groups of Shop floor workers in different manufacturing rooms were exposed to varying levels of illumination (levels illumination varied down to some workers working in near dark conditions) and their productivity was assessed. It was found that no matter how the lighting was varied, the workers productivity increased. Follow up studies by F. Roethlisberger and Elton Mayo of the Harvard Business School led the researchers to conclude that the managerial attention paid to the workers made them feel important which in turn motivated them to work harder in spite of the physical conditions. This effect is called the 'Hawthorne Effect'- 'response of experiment subjects being studied' (and feeling important) instead of the intended stimuli. This development laid the foundation for the growth of the human relations school. Personnel departments and other employees' accommodations in contemporary organisations are vestiges of the HR Movement.

In spite of differences in their approaches, a strong agreement has developed among modern scholars in the field of Organizational Behaviour on the pervasive influence of organizational culture in organizational life. Robbins and Judge (2007:572) argue that culture is an independent variable that affects an employee's attitudes and behaviour. Organisational culture is believed to impact on the communications, coordination and cooperation of members in an organisation. It has also been asserted that culture is an autonomous variable and determines human nature (Vredenburgh and VanFossen (2010).

Though studies that contest the existence of a relationship between the concepts are available but they are considered contentious and have not been sufficiently strong to discourage enthusiasm on the relationship. For instance, Lim (1995) carried out a review of some early empirical studies on the influence of organisational culture on organisational performance and concluded that there was no firm relationship between the two variables. Further, Pearlberg \& Perry (2007) noted that empirical research on the impact of values on employee or organisational performance has produced mixed results. It can be observed that claims of no firm relationship or the complete lack of it have been made lame by issues of conceptualization of the variables and methodological rigor (Lim, 1995). In addition, studies indicating lack of relationship between the concepts are few compared to those supporting it.

The growth of empirical studies supporting the existence of a relationship between organizational culture and organizational performance has been continuously tremendous. An early empirical study that provides strong support for the relationship between organizational culture and organizational performance was carried out by Cameron and Freeman (Jaakson, 2008). The authors "tested organisation effectiveness and culture type in 334 US Colleges and Universities and found that higher effectiveness was associated with adhocracy culture". Organisations practicing adhocracy were defined as those that are externally oriented, dynamic, aimed at growth and influencing the future. According to Jaakson (2008), this culture is largely based on the values of entrepreneurship, flexibility, creative experimentation, risk and external positioning.

Some more recent empirical studies have provided more enthusiasm on the relationship. Some of the best known recent empirical studies on culture have been conducted by measuring it in terms of values (Minkov \& Blagoev, 2009). Considered as some of the best known cultural factors, values are abstract ideals for assessing good and bad. The relationship between values and performance is now well recognised. For instance, Dolan et al. (2004) remarked that values are long-term predictors of behaviour. They guide social actors in their selection of behaviour. Pearlberg \& Perry (2007) conducted an empirical study on the implementation of a new performance management system in a U. S Department of Defence Installation and revealed that values were motivating to employees. A considerable consensus exists on the Value Survey Model (VSM) developed by Hofstede as a framework for understanding values (Cohen, 2007) and more convincing results on Culture studies have been produced from its application. For instance, Cohen (2007) applied the Dorfman and Howell's cultural dimensions scale adapted from Hofstede's model in a survey design and examined the relationship between personal cultural values (individualism-collectivism, power distance, uncertainty avoidance, and 
masculinity- femininity) and organisational citizenship behaviour as well as In-role performance of teachers of five cultural groups (secular Jews, orthodox Jews, Kibhutz, Druge, and Arabs) in Israel. He found that both membership in cultural group and cultural values were substantially associated with OCB and In-role performance. Cohen (2008) further examined the relationship between individual values, social justice variables as well as commitment dimensions and In-role performance and organisational citizenship behaviour and found that individual values were related to three of the behavioural outcomes, over and above the effect of the social exchange variables.

Interestingly, Bello (1985) found that Nigerian employees view their promotion at work and job successes as a function of managerial favours and fate rather than hard work. The inclination towards the supernatural to the explanation of events is a cultural attribute of Africans. Ahiauzu (1999:11-21) identifies the colonial forced labour system, the 'stranger' concept in African communities, Ethnic Affinity, kinship, the Belief system and personal respect as cultural factors to explain the relative poor attitude of the African at wage employment.

\section{A Model of Culture Effects on Performance: Culture, Value of Reward, Role Perception and Organisational Performance Relationship}

In order to provide a clearer perspective on the relationship between culture and performance as was called for by Aycan (2000), this article draws on the Porter and Lawler Motivation Model (Weinhrich \& Koontz, 1994:472) and the literature on culture. It has been noted that organisational performance is an aggregate of work performance (Ployhart, 2006) which is in turn influenced by the value of rewards (Weinhrich \& Koontz, 1994:472). The powerful influence of rewards on Performance is well demonstrated by an extensive body of organisation literature (Chiang \&Birtch, 2007). The view has also been expressed that perceptual and cognitive mechanisms are not culture-free and that there is no such thing as immaculate perception (Lukes, 2000). It is important to realize that the audience at which a particular reward is directed is important. An audience may be motivated by a reward that may not motivate another audience. By extension, employees from one culture may be motivated by a reward that may not motivate employees from another culture (Costantino and Merchant, 1966:190). Cultural differences can influence the value placed on a given reward and consequently its motivational impact (Schemerhorn, Hunt and Osborn, n.d:72). Rewards that are effective in one culture may not be effective in another culture. Some social (perceived spiritual) rewards can be considered more valuable than monetary rewards, depending on culture. Furthermore, it has been argued that the perception of our needs (rewards) is influenced by the environment (Weihrich \& Koontz, 1994:463). Since Culture is an environmental factor, its influence on rewards perception is therefore implied. Societies and individuals perceptions of a given reward vary according to their various cultures and individual subjectivities (Cohen, 1968:77; Giddens, Duneler \& Appelbaum, 2005:A15). These differences give rise to differences in effort expended to achieve a given reward. Individual value differences lead to varying interpretations of a given situation and hence actions (Cohen, 2007). Particularly, Chiang \& Birtch (2007) found that Culture has an important role in shaping reward preferences. Thus Culture may influence Work Performance through its impact on value of Reward.

In addition, Porter and Lawler (Weihrich \& Koontz, 1994:473) indicates that role perception influences Performance. In the extant literature, role orientation is conceived to be a set of beliefs and is shaped by the environment, which encompasses culture (Parker, 2007). Values which are components of culture influence an individual's perception, interpretation and reaction on a given situation (Aycan, 2000). Cohen (2008) also suggests that the way an individual perceives his work role is influenced by his value orientation. This is consistent with Ogunniyi's (1989:189) suggestion that culture controls perception. Culture creates and shapes the role of the individual in the workplace. For instance, the African Industrial man under woman's supervision may perceive his role differently from when he is supervised by a man in the same workplace. Similarly, the he may define his role differently on issues concerning his kith and kin in the workplace. Religious and Traditional matters can make employees to shift from objectivity in defining their roles in the workplace. Furthermore, a younger African under the supervision of his elder in the workplace may perceive his performance obligatory and define his role broader than when under the supervision of a younger person. Following from the above, it is logical to uphold the position that a relationship exists between culture and work performance and hence the performance of business organisations. The chart below summarises the relationships among the variables. 


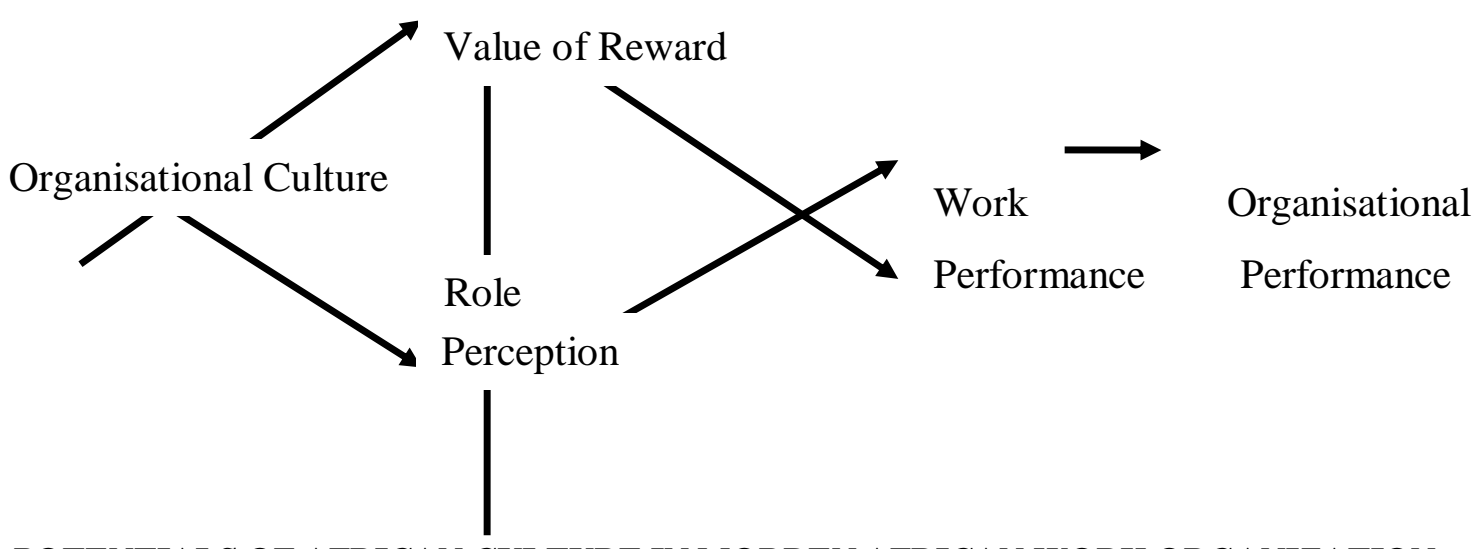

POTENTIALS OF AFRICAN CULTURE IN MORDEN AFRICAN WORK ORGANIZATION

Based on the preceding section, this article examines some dimensions of African culture that can be useful for the formation of effective organizational culture in African workplaces. The dimensions are social support, accommodation at workplaces, religious referencing, respect for elders and ethnic diversification.

\section{Social Support}

In certain circumstances in an African setting, social support may be considered more valuable than monetary support. Social Support is a highly valued indigenous cultural practice in Nigeria. The way it is practiced is in line with the cooperative, comprehensive and communal orientation of the Nigerian culture and has reciprocal connotations (Ngwoke, 2005:41-43; 162). Individuals in families, communities, clans or tribes cooperate to provide social support to members whenever the need arises. Social groups are formed or joined for the purpose of social support. In recent times, these groups transcend tribal boundaries and are sometimes run as cooperative societies. Social support is provided to needy members of groups in the form of personal services and attendance at their social events in order to comfort, encourage, felicitate or to provide solidarity as the case may be. It is also provided as material assistance.

Social support received reflects social acceptance and recognition for the individual. It is a source of esteem and social rating at the local community. Due to the benefits derivable from the practice, social support promotes individual reciprocal commitment as well as loyalty to their cultural groups.

The practice of social support in the Nigerian culture can be applied to Work organisations in the country to elicit organisational commitment and ultimately the improvement of work performance. A Nigerian employee who receives social support from his organisation is likely to reciprocate by increasing his commitment to the organisation and increase his work performance more than the one who does not. Social support in the organisational context can be in the form of supervisor understanding, attendance of supervisor and work colleagues at subordinates' social events or assistance to employee relations when possible. For instance, by attending employees' social events, an organisation demonstrates support to the employees and in turn fosters reciprocal attachment by the employees. Social support can save a lot of man-hours that may be lost due to stress and ill-health of employees arising from diverse and complex social responsibilities peculiarly associated with the Nigerian culture.

\section{Accommodation within Workplaces}

Africans are collectivistic (Ahiauzu, 1999:216) and leisurely (Nduka, 1961:9) in nature. In traditional self-employment, they live by their farms or fishing grounds or have their workshops within their dwelling places and do not need to go far to work as obtainable in modern industrial work organisation (Giddens, Duneler \& Appelbaum, and 2005:96).This perhaps compensates for their leisurely life style. In addition, living at the workplace affords a worker opportunity to have more resources, especially social, for the job. Their hardworking nature in self-employment as observed by Ahiauzu (1999:11) may be attributable, in part, to the fact that these working and dwelling places may not be separable.

It is reasonable to believe, therefore, that living together at the modern work place is in consonance with these presumably high performance generating traditional work features. Family members can assist the employee in the performance of certain duties. In some Nigerian Universities, for instance, children have been observed to assist their mothers (employed as cleaners and are privileged to live on campus) in their cleaning work when convenient. In addition, accommodation within work places can encourages employees to readily provide emergency or overtime services when necessary.

Time is a vital resource for organisations and this could be gained in several ways by accommodating workers at work places. For Africans, who are noted for their familism and excessive affectivity(Domingues, 
2009), accommodation at the work site will likely remove anxiety of workers over families, especially the safety of children, and hence release time for overtime work, social support and co-worker assistance activities.

Living at the workplace can avoid exhaustion of workers due to transportation difficulties associated with African cities. The saved energy can be productively used in the workplace. It can also avoid loss of resources for the worker due to long distance travels and hence contribute to increasing the commitment of the worker.

\section{Religious Referencing}

Nigerian culture is highly mystical (Nduka, 1961:9). This culture has been extended to their acceptance and practice of Christianity and Islam which have become powerful motivating factors for their behaviour (see Magill and Delgado, 2000:1094). In the Nigerian culture, moral rectitude, control and social order are elicited from individuals based more on religion than reason and impersonal laws as is mainly in Western culture which is prevalent in formal organisations. The fear of punishment from the supernatural is an effective check on immoral conduct (Nduka, 1961:104-107). The tremendous growth and success of religion in Nigeria, especially Christianity, is an indication of how religion is influential in the lives of the people. Religion has become a melting pot for Nigerians with the result that allegiance and cooperation have been elevated above tribal affiliations in these organisations. Followers often comply with religious requirements as obligations. While some behaviours are highly emphasized by some religious groups others are either neglected or ignored in accordance with their norms and values.

In view of the above, the influence of religion on Africans can be exploited to improve organisational culture and hence performance. For instance, it has been argued that group membership influence behaviour and that the groups individuals decide to join or are members convey information about their characteristics. For instance, trustworthiness of prospective employees has been determined by religious group membership (Frank, 1994:207).Similarly, trustworthiness can be assured by invoking religious faith. For instance requirement for recommendations and guarantees from recognised and respected priests, pastors or imams at recruitments are likely to make workers to be more dependable, honest, faithful and trustworthy at their workplaces. This cultural approach is consistent with the suggestion by Ahiauzu (1999:213) that the 'induction of new employees into organisation should include an oath-taking ritual'.

\section{Respect for Elders (Supervisor- Subordinate Age ratio)}

Chronological age is highly regarded in African indigenous culture. Every individual is accorded respect by younger people in the family, community and other cultural groups in the society. Respect for elders is demonstrated through qualified obedience and running of errands for them. It is regarded as good conduct and is rewarded mostly spiritually through blessings and sometimes materially from the concerned elders. In matters of leadership, gerontocratic practices such as the elders first principle, continue to prevail in majority of Nigerian communities. In other words, the authority of a member of a social group in traditional settings increases as the age of the member increases (Ahiauzu, 1999:215; Giddens, Duneler \& Appelbaum, 2005:104). The eldest has the most authority and assumes leadership of the group or leadership is delegated to the next eldest. Similarly, loyalty to the leader increases with the age of the leader. Child-rearing practices in African communities, where every adult in a neighbourhood contributes to the discipline of the child, greatly reinforce the leadership tradition. Regard for Age can also be noticeable in the African informal relations in modern work places where the phenomenon is formally unrecognised. It is therefore possible that increasing age ratio between the supervisor and the subordinate as an aspect of organizational culture will lead to increases in organizational performance in Nigerian Work Places.

\section{Ethnic Diversification}

Nigeria has diverse ethnic groups. Ethnic Affiliation is believed to have a profound negative effect on work output. Experience has shown that Africans are excessively affective especially towards their relatives and this has compromised discipline and encouraged complacency in Nigerian workplaces. It is likely that carefully diversifying the ethnic composition of the workforce in organisations in the country will promote competition and effectively enhance workplace discipline and hence organizational performance. It is well supported that workforce diversity promotes performance (Showbridge, 2006; Pitts and Wise, 2010).

\section{Conclusion}

In this article, the potential of organisational culture as a determinant of business performance has been elaborated. While very strong evidence is yet to be provided against the existence of the relationship, studies increasingly point to the potential link between the two variables.

This paper contributes more to the understanding of the concept of organisational performance by proposing a model of the effects of culture on the phenomenon. Using the Porter and Lawler Motivation Model, it has proposed how culture may be related to work performance and hence organisational performance by 
incorporating the concepts of value of reward and role perception as intervening variables in the relationship. Incorporating the intervening variables broadens the scope of the cultural approach in the management of performance.

In order to capitalize on the emerging potential of culture, this article identified social support, accommodation at work places, religious referencing, Respect for Elders (supervisor-subordinate age ratio) and ethnic diversification as some cultural determinants that can be useful in managing organizational performance in Nigeria. Careful application of local societal cultural factors as enumerated above in the formulation of organizational cultures can lead to substantial improvement of performance in organizations in Nigeria.

The chain of variables in the relationship between Culture and Organizational Performance as proposed in this article may not be limited to reward perception and role Perception. Many other variables are equally likely. In addition, there could be many more useful cultural dimensions which can improve organisational performance that could be identified. Furthermore research is needed to test the relationships that have been identified.

\section{References}

[1]. Ahiazu, A. (1999). The African Industrial Man. Port Harcourt: CIMRAT Publications.

[2]. Aycan, Z. (2000). "Cross-Cultural and Organizational Psychology: Contributions, Past Developments, and Future Directors". Journal of Cross-Cultural Psychology, http://cc.sagepub.com/cgi/content/abstract/31/1/110 (accessed 30 October, 2008).

[3]. Bello, J.A. (1985). "Developing Managerial Leadership and Followership Styles in $\quad$ Nigeria" in Inanga, E.L. (Ed.). Managing Nigeria's Economic System: A Book of Readings. Heinemann Educational Books (Nigeria) Limited.

[4]. Bocock, R (1981). "Society and Culture" in The Open University Social Sciences: A Second Level Course: An Introduction to Sociology. Milton, Keynes: The Open University Press.

[5]. Chiang \& Birch (2007). "The Transferability of Management Practices: Examining Cross-National Differences". Human Relations, 24(1): 80-96. Available from: http://hum.sagepub.com/cgi/content/abstract/60/9/1293(accessed 30 October, 2008.

[6]. Cohen, A. (2007). "One Nation, Many Cultures: A Cross-Cultural Study of the Relationship Between Personal Cultural Values and Commitment in Workplace to In-role Performance and Organizational Citizenship Behaviour". Cross-Cultural Research, 41(3):273-300. Available from: http://ccr.sagepub.com/cgi/content/abstract/41/3/273 (accessed 30 October, 2009).

[7]. Cohen, A. and Keren D. (2008). "Individual and Social Exchange Variables: Examining Their Relationship to and Mutual Effect on In-Role Performance and Organizational Citizenship Behavior". Group \& Organization Management, 33(4), 425-452. Available from: http://gom.sagepub.com (accessed 31 October, 2008).

[8]. Cohen, P. S. (1968). Modern Social Theory. London: Heinemann Books Ltd.

[9]. Cole, W.E. \& Montgomery, C.S. (1961). High School Sociology. Allyn and Bacon, Inc.

[10]. Costantino, C.A. \& Merchant, C.S. (1996). "Designing Conflict Management Systems: A guide to Creating Productive and Healthy Organization". John Wiley \& Sons, Inc.

[11]. Dolan et al. (2004). "Exploratory Study of Within-Country Differences in Work and Life Values: A Case of Spanish Business Students". International Journal of Cross-Cultural Management, $4(2): \quad 157-180 \quad$ Available from:http://com.sagepub.com/cgi/content/abstract/4/2/157(accessed May 30, 2008).

[12]. Domingues, J.M. (2009). "Global Modernization, 'Coloniality' and a Critical Sociology for Contemporary Latin America". Theory, Culture and Society, 26(1): 112-133.Available from: http://tcs.sagepub.com/cgi/content/abstract/26/1/112-133 (accessed 16 April, 2009).

[13]. Frank, R. H. (1994). Microeconomics and Behavior. New York: McGraw-Hill, Inc.

[14]. Ghosh, P \& Geetika (2007). "Recruitment Strategies: Exploring the Dimensions in the Indian Software Industry". Asian Journal of Management Cases, 4(1), 5-25. Available from: http://ajc.sagepub.com/cgi/content/abstract/4/1/5 (accessed 18 October, 2008).

[15]. Giddens, A., Duneler, M. \& Appelbaum, R. (2005). Introduction to Sociology. New York: W. W. North and Company.

[16]. Hill, V. and Carley, K. M. (2008). "Win Friends and Influence People: Relationships as conduits of Organizational Culture in Temporary Placement Agencies". Journal of Management Inquiry, 17(4), 369-379. Available from: http://jmi.sagepub.com/17/4/369 (accessed 6 April, 2011).

[17]. Jaakson, K. (2008). "Students' Perception about University Value: Some Influencing Factors". Journal of Human Values, 14(2), 169-180. Available from: http://jhv.sagepub.com/content/14/2/169 (accessed 9 April, 2011).

[18]. Jaskyte, K. \& Dressler, W. W. (2004). "Studying Culture as an Integral Variable: Organisational Culture and Innovation in a Group of Non-profit Organisations". Field Methods, 16(3), 265-284. Available from: http://fmx.sagepub.com/cgi/content/abstract/16/3265 (accessed 15 April, 2009).

[19]. Lim, B. (1995). "Examining the Organizational Culture and Performance Link". Leadership \& Organizational Journal, 16(5): 1620. MCB University Press Limited.

[20]. Loasby, J. B. (2007). "The Ubiquity of Organization". Organization Studies, 28(11):129-1759. Available from: http://oss.sagepub.com/cgi/abstract/28/11/1729 ( accessed 24 October,2008).

[21]. Lukes, S. (2000). "Different Cultures, Different Rationalities". History of Human Sciences, 13(1): 3-18. Available from:http://hhs.sagepub.com/cgi/content/abstract/13/1/3 (accessed 2 April, 2010).

[22]. Lynham, S.A. and Conningham, P.W. (2006). "National Human Resource Development in Transitioning Societies in the Developing World: Concept and Challenges". Advances in Developing Human Resources, 8(1):116-135. Available from: http://adh.sagepub.com/cgi/content/abstract/8/1/116 (accessed 23 May, 2008).

[23]. Magill, F. N. \& Delgado, H.L. (Eds) (2000). International Encylopaedia of Sociology, Vol.2. Fitzroy Dearborn Publishers.

[24]. Minkov, M \& Blagoev, V. (2009). "Cultural Values Predict Subsequent Economic Growth". International Journal of CrossCultural Management, 9(1):5-24. Available from: http://ccm.sagepub.com/cgi/content/abstract/9/1/5 (accessed 29 April, 2009).

[25]. Morrill, C. (2008). "Culture and Organization Theory". The Annals of the American Academy of Political and Social Science, 6(1):15. Available from: http://ann.sagepub.com/cgi/content/abstract/619/1/15 (accessed 24 October, 2008).

[26]. Nduka, O. (1961). Western Education and Nigerian Cultural Background. London: Oxford University Press.

[27]. Ngwoke, E. (2005). The Eucharist and Social Responsibility towards the Poor. Enugu: Snaap Press Ltd.

[28]. Njoku, L. (2011) "Parents lose confidence in Enugu's public primary school”. The Guardian, P. 45. 
[29]. Ogunniyi, M.B. (1989). "Traditional African Culture and Modern Science”. In P. Ekeh \& Ashiwaju(Eds), Nigeria Since Independence: The First Twenty-five Years. Volume vii, Culture. Heineman Educational Books.

[30]. Olisa, M.S.O. (1985). "Performance of Nigerian Public Corporations". In Nwosu, H.N. (Ed.), Problems of Nigerian Administration. Enugu: Fourth Dimension Publishing Co., Ltd.

[31]. Ozcelik, G. \& Ferman, M. (2006). "Competency Approach to Human Resources Management: Outcomes and Contributions in a Turkish Cultural Context". Human Resources Development Review, 5(1) 72-91. Available from: http://hrd.sagepub.com/cgi/content/abstract/5/1/72 ( 23 May, 2008).

[32]. Palich, L.E. \& Gomez-Mejia, L.R. (1999). "A Theory of Global Strategy and Firm Efficiencies: Considering Cultural Diversity". Journal of Management, 25(4): 587-606. Available from: http://jom.sagepub.com/cgi/content/abstract/25/4/587 (accessed 24 April, 2008).

[33]. Paprock, K.E. (2006). "National Human Resource Development in Transitioning Societies in the Developing World: Introductory Review". Advances in Developing Human Resources, 8(3):12-27. Available from: http://adh.sagepub.com/content/abstract/8/1/587 (accessed 30 October, 2008).

[34]. Parker, S. K. (2007). "That is my job': How Employees' Role Orientation Affects Their Job Performance". Human Relations, 60(3): 403-434. Available from: http://adh.sagepub.com/cgi/content/abstract/60/3/403 (accessed 30 October, 2008).

[35]. Pearlberg, L. E. \& Perry, J. L. (2007). "Values Management: Aligning Employee Values and Organisation Goals". The American Review of Public Administration, 37(4): 387-408. Available from: http://arp.sagepub.com/cgi/content/abstract/37/4/387 (accessed 28 May, 2008).

[36]. Peters, M. A. (2009). "Education, Creativity and the Economy of Passions: New Forms of Educational Capitalism". Thesis Eleven, 96(1): 40-63. Available from: http://the.sagepub.com/cgi/content/abstract/96/1/40 (accessed 3 April, 2010).

[37]. Pitts, D. W. and Wise, L. R. (2010). "Workforce Diversity in the New Millennium: Prospects for Research". Review of Public Personnel Administration, 30(1), 44-69. Available from: http://rop.sagepub.com/content/30/1/44 (accessed 3 March, 2011).

[38]. Ployhart, R. E. (2006). "Staffing in the $21^{\text {st }}$ Century: New Challenges and Strategic Opportunities". Journal of Management, 32(6), 868-897. Available from: http://jom.sagepub.com (accessed 28 January, 2008).

[39]. Rich, G. A. (1997). "The Sales Manager as a Role Model: Effects on Trust, Job Satisfaction and Performance of Sales People". Journal of Academy of Marketing Science, 25(4):319-328.

[40]. Robbins, S. P. and Judge, T. A. (2007). Organizational Behavior. New Jersey: Prince-Hall Inc.

[41]. Sachau, D. A. (2007). "Resurrecting the Motivation-Hygiene Theory: Herzberg and the Positive Psychology Movement". Human Resources Development Review, 6(4): 377-393. Available from: http://hrd.sagepub.com/cgi/content/abstract/6/4/377 (accessed 18 May, 2009).

[42]. Salaman, G. (1980). "Organisation”. In The Open University Social Sciences Second Level Course: An Introduction to Sociology. Milton, Keynes: The Open University Press.

[43]. Schermerhorn, J. R., Hunt, J. C., Osborn, R. N.(n.d.). Basic Organisational Behaviour. New York: John Wiley.

[44]. Shoobridge, G. E. (2006). "Multi-ethnic Work Force and Business Performance: Review and Synthesis of the Empirical Literature". Human Resource Development Review, 5, 92-137. Available from: http://hrd.sagepub.com/cgi/content/abstract/5/92 (accessed 21 November, 2007).

[45]. Weihrich, H. \& Koontz, H. (1994). Management: A Global Perspective. New York: McGraw-Hill, Inc.

[46]. Vredenburgh, D. \& VanFossen, R. (2010). "Human Nature, Organizational Politics, and Human Resources Development". Human Resource Development Review, 9(1): 26-47. Available from: http://hrd.sagepub.com/content/9/1/26 (accessed 5 September, 2010).

[47]. Yeganeh, H. \& Su, Z. (2006). "Conceptual Foundations of Cultural Management Research". International Journal of Cross Cultural Management, 6(3):361- 376. Available from: www.sagepublications.com (accessed 29 April, 2009).

[48]. Yesufu, T. M. (1984). The Dynamics of Industrial Relations: The Nigerian Experience. Ibadan: University Press Limited. 